\title{
The Study of James Rosenau's Affiliation Theory with an Emphasis on the Role of Individual and International System Variables in the Analysis of Regionalism in the Second Pahlavi and Islamic Republic of Iran
}

\section{El estudio de la teoría de la afiliación de James Rosenau con énfasis en el papel de las variables del sistema individual e internacional en el análisis del regionalismo en la Segunda Pahlavi y la República Islámica del Irán}

\author{
Hossein Hassanpour Dehnavi \\ Ph.D. Student, Department of Political Science, Khorasan e Razavi Science and Research \\ Branch, Islamic Azad University, Neyshabur, Iran \\ Orcid https://orcid.org/0000-0002-6345-833X

\section{Ahoura Rahbar} \\ Assistant Professor, Department of Political Science, Neyshabur Branch, Islamic Azad \\ University, Neyshabur, Iran \\ Orcid https://orcid.org/0000-0002-2911-1703 \\ Ahmad Bakhshi \\ Associate Professor, Department of Political Science, Birjand University, Birjand, Iran \\ Orcid https://orcid.org/0000-0002-5443-5574

\section{Ali Mohammadzadeh} \\ Assistant Professor, Department of Political Science, Shahroud Branch, Islamic Azad \\ University, Shahroud, Iran \\ Orcid https://orcid.org/0000-0002-1802-8525
}

Received 09-08-20 Revised 10-10-20

*Correspondence

Email: a.rahbar@gmail.com
Accepted 20-12-21 On line 01-29-21

Cite as:
Hassanpour, H., Rahbar, A., Nakhsi, A., \& Mohammadzadeh, A. (2021). The Study of James Rosenau's Affiliation Theory with an Emphasis on the Role of Individual and International System Variables in the Analysis of Regionalism in the Second Pahlavi and Islamic Republic of Iran. Propósitos y Representaciones, 9 (SPE2), e958. Doi: http://dx.doi.org/10.20511/pyr2021.v9nSPE2.958 
The Study of James Rosenau's Affiliation Theory with an Emphasis on the Role of Individual and International System Variables in the Analysis of Regionalism in the Second Pahlavi and Islamic Republic of Iran

\section{Summary}

Different theoretical approaches can be used to analyze countries' foreign policy and regionalism. The present study intends to study and compare the policy of regionalism of Iran in the second Pahlavi era and the Islamic Republic based on the theoretical approach of James Rosenau, using the variables of decision-making personality, role, government, society and international system variables. Iran's regionalization policy during the Second Pahlavi period was in line with the structure of power in the international system. At the same time, Iran, in this period influenced by the structure of the bipolar system and the Cold War, also sought to gain supremacy and leadership in the region, as the most important person in foreign policy decisionmaking and in the personality of Mohammad Reza Shah. On this basis, we can say that the two variables of the international system and the decision-making personality were the most important variables influencing the process of foreign policy and regionalism of Iran during this period. In the Islamic Republic, with the formation of ideological elements such as the construction and nature of political power based on the velayat-e faqih and the idea of issuing a revolution, the policy of regionalism was in conflict with the structure of power in the international system and in line with ideological foundations and interests. Accordingly, the two variables of the international system and the decision-making personality were the most important variables influencing the process of foreign policy and regionalization of Iran during this period. The purpose of this paper is to use a descriptive-analytical method, a comparative study and to use the historical data to study the effect of each of these variables on the regionalization process.

Keywords: Foreign Policy, Regionalism, James Rosenau's Theory, Second Pahlavi Period, Islamic Republic Period.

\section{Resumen}

Se pueden utilizar diferentes enfoques teóricos para analizar la política exterior y el regionalismo de los países. El presente estudio pretende estudiar y comparar la política de regionalismo de Irán en la segunda era Pahlavi y la República Islámica con base en el enfoque teórico de James Rosenau, utilizando las variables de personalidad decisoria, rol, gobierno, sociedad y variables del sistema internacional. . La política de regionalización de Irán durante el segundo período Pahlavi estaba en consonancia con la estructura de poder en el sistema internacional. Al mismo tiempo, Irán, en este período influenciado por la estructura del sistema bipolar y la Guerra Fría, también buscó ganar supremacía y liderazgo en la región, como la persona más importante en la toma de decisiones de política exterior y en la personalidad de Mohammad Reza Shah. Sobre esta base, podemos decir que las dos variables del sistema internacional y la personalidad decisoria fueron las variables más importantes que influyeron en el proceso de política exterior y regionalismo de Irán durante este período. En la República Islámica, con la formación de elementos ideológicos como la construcción y naturaleza del poder político basado en el velayat-e faqih y la idea de hacer una revolución, la política del regionalismo estaba en conflicto con la estructura de poder en el ámbito internacional. sistema y en consonancia con los fundamentos e intereses ideológicos. En consecuencia, las dos variables del sistema internacional y la personalidad decisoria fueron las variables más importantes que influyeron en el proceso de política exterior y regionalización de Irán durante este período. El propósito de este trabajo es utilizar un método descriptivo-analítico, un estudio comparativo y utilizar los datos históricos para estudiar el efecto de cada una de estas variables en el proceso de regionalización.

Palabras clave: política exterior, regionalismo, teoría de James Rosenau, segundo período Pahlavi, período de la República Islámica. 


\section{Introduction}

Foreign policy is an area in which those countries pursue their national interests beyond their territorial borders. The national interests of the countries are in different situations (common interests, parallel interests, divergent interests and conflicting interests). Given the national interests of one country in relation to any of the four above-mentioned situations, the nature of the country's foreign policy and the type of orientation will be determined. It is in the common interest that regionalization policy becomes relevant and objective. So the point of departure for regionalism policy is to have common interests. This means that unless the countries in the region have a mutual understanding of one another's interests, successful regionalization policy will not be possible. In James Rosenau's view, in foreign policy decision making, the cause of governments' political behavior relates to a set of five factors: the decisionmaking personality variable, the role and extent of decision-making authority, the government bureaucratic variable, the community variable, and the international system variable. In this way, the influential components of foreign policy and consequently regionalization policy in Iran can be studied and compared with Rosenau's theoretical approach in different periods. The present paper attempts to study, compare, and evaluate the regionalization policy of Iran in the second Pahlavi period and the Islamic Republic based on Rosenau's theoretical approach. Therefore, the question of the present research is what are the similarities and differences between the regionalization policy of Iran during the two Pahlavi periods and the Islamic Republic based on James Rosenau's theory?

\section{Background}

There are many sources on foreign policy and regionalism in the Second Pahlavi era and the Islamic Republic, some of which are cited: Houshang Mahdavi (2010), in his book "Foreign Policy of Iran during the Pahlavi Period (1942-1978)" Realistically and without prejudice to the assessment of Iranian foreign policy during this period. On this basis, besides expressing the shortcomings of foreign policy of the Pahlavi era, he outlined its positive aspects, including efforts to maintain peace in the region, to establish friendly relations with neighboring countries. Barzegar (2009), in the article "Regionalism in Iranian Foreign Policy", examines the importance of regionalism in Iranian foreign policy. Although some viewpoints view the features of power and politics in Iran in a way that makes it difficult for any political, security, economic and cultural co-operation at the regional level to be made possible, political change, Security and geopolitics in the region have strengthened the position of regionalism in Iranian foreign policy since the events of September 11th. Sadeghi (2017) has attempted to evaluate the foreign policy of the Islamic Republic of Iran in the framework of Structural Realism. He believes that the theoretical foundations and practical approaches of the foreign policy of the Islamic Republic of Iran are incompatible with each other and are in fundamental contradiction with the hegemonic structure of the post-Cold War international system. Zarei and Zeinivand (2013), in the article "The Territory of Great Iran: The Basis for a Regional System", have identified three components of territorial unity, common history and destiny and common culture as unifying variables in the territory of Iran that can be co-opted by others. The actors of the region helped to create a successful regional system. Sajjadpour (2014), in an article entitled "Area and Regionalism in Iranian Foreign Policy", seeks to answer these two questions: What is the relationship between regionalism and foreign policy? And what is the role of regionalism in Iranian foreign policy? In this regard, he has considered the role of regionalism in Iranian foreign policy in three dimensions: structural, geopolitical and brokerage. In an article entitled "Neo-regionalism in Iranian Foreign Policy", Dehshiri (2014) considered the foreign policy of the Islamic Republic of Iran as an alternate field between regionalism and internationalism. In this article, while exploring the capabilities and achievements of the Islamic Republic of Iran in the field of regionalism and trans-regional communications, he has explored ways to strengthen the capabilities and achievements of neo-regionalism in the foreign policy of the Islamic Republic of Iran. Zarei (2015), in the article "Regionalism and its Challenges in the Foreign Relations of the Islamic Republic of Iran" states that the Islamic Republic in the years after the 
The Study of James Rosenau's Affiliation Theory with an Emphasis on the Role of Individual and International System Variables in the Analysis of Regionalism in the Second Pahlavi and Islamic Republic of Iran

imposed war realized the necessity of paying attention to regional cooperation. He claims that because of security threats to the country over the past few decades, regionalism in the foreign policy of the Islamic Republic of Iran has been largely political and security-related. However, the successful experiences of regionalism in the world are influenced by economic and nonsecurity trends. From a number of sources related to the subject, it can be said that, in spite of their variety, these works have primarily been looked at on a case-by-case basis. Secondly, it has more to do with Iran's relations with the countries of the region with a historical perspective than with a functional approach to foreign policy. In the present article, however, using the James Rosenau's theory, it is attempted to compare and analyze the theoretical approach of Iran's regionalism in the Second Pahlavi period and the Islamic Republic.

\section{Theoretical framework and model of analysis}

In James Rosenau's view, in foreign policy making, the cause of governments' political behavior relates to a set of five factors: 1 - The decision-making personality variable, 2 - The role and extent of decision-making powers, 3 - The government bureaucracy variable, 4 - The Society variable, 5 Variables of the International System. He quantifies the influence of each of these variables in the development of foreign policy, influenced by factors such as actor power, which divides countries into large and small groups, the open and closed nature of social structure, the permeability of cultural structure, and subject areas (Rosenau, 1971: 98). Below these variables are explained and discussed.

\section{The individual or personality of the decision maker variable}

The first variable in Rosenau's theory of continuity is the individual variable that encompasses the unique characteristics of a country's foreign policy-makers. This variable encompasses all aspects of the decision maker, i.e., one's values, talents and past experiences. Features such as hurrying cautiously, prudence against anger, prudence against criminality, humility against arrogance and pride, superiority against inferiority, creativity against destruction, overconfidence, bravery, courage In the face of fear, resoluteness against shakiness, tolerance against corruption, have a great impact on foreign policy (Mohammadian \& Rezaei, 2015: 6). The fact is that it is ultimately these special individuals who formulate and proclaim political decisions, and therefore the personality, mental and psychological characteristics of these individuals influence the decisions and give them a specific color and smell and direction. The extent of this influence depends on the competence of the institutions and the degree of systematicity of the political system. As the system becomes more cohesive, the role of the characters is reduced, and on the contrary, in the societies in which institutions are at an early stage, the role of the characters is increased (Naqibzadeh, 2009: 62).

\section{Role and extent of decision-making authority}

This variable stems from the role that the decision maker occupies, no matter what personality traits the occupiers play (Mansouri Moghaddam and Ismaili, 2011: 288). These variables are usually defined as job descriptions or expected behavioral rules from authorities. By officials, system leaders and individuals such as the president, ministers, high-ranking officials, parliamentarians and other elites involved in foreign policy. Regardless of a person's psychological personality, when he or she assumes a specific role, his or her behavior changes significantly according to the expectations that people have.

\section{Bureaucratic variables}

This variable is referred to government structural aspects. The complex structure of a government, the relationships of intergovernmental organizations and, ultimately, the experts within an organization, formulate and provide suggestions and outlines of foreign policy decision-making, and no decision-maker is capable of these decision-making considerations. Especially in the widespread bureaucratic systems of Western governments, this factor and variable is more prevalent. From Rosenau's point of view, as we move from developed and politically open societies to closed societies, the role of bureaucratic institutionalism is diminished and the impact of environmental determinism stemming from international 
reservations and individual dictatorships increases. (Seifzadeh, 2003: 357).

\section{Community Variable}

This variable includes non-governmental dimensions of a society that affect external behavior. Value orientations of society, the degree of national unity, and the degree of industrialization are variables that contribute to determining the content of a country's foreign ideals and policies (Mohammadian \& Rezaei, 2015: 5). In this model a set of factors and resources that influence foreign policy decision-making are examined. The social and economic system is also an important factor influencing this process. Part of the political-social system involved in this is the party system and influence groups. In democratic countries, the foreign policy of the country is influenced by the party system and the conditions of the parties. Parties are, however, among the actors concerned with foreign policy, but the degree of its importance depends on the circumstances of society and its specific requirements. Public opinion, as an independent element, is also trying to influence foreign policy (Fath Tabar Firouzjai, 2015: 63).

\section{International system variable}

According to Rosenau, these variables include the human and non-human aspects of the external environment of a society or any action that takes place abroad and condition the decision-makers' foreign policy options (Rosenau, 1971: 109). That is, they are foreign to the country under study (Azgandi, 2007: 16). In its proposed approach, Rosenau seeks to assess the impact of each of the domestic and international factors on the formulation and implementation of foreign policy by providing some kind of causal explanation in foreign policy. He believed that the options and circles of decision-makers' choices and activities were influenced by cultural norms, histories and historical traditions, demands stemming from both internal and external systems (Mohammadian and Rezaei, 2015: 5). On this basis, regionalism is analyzed in

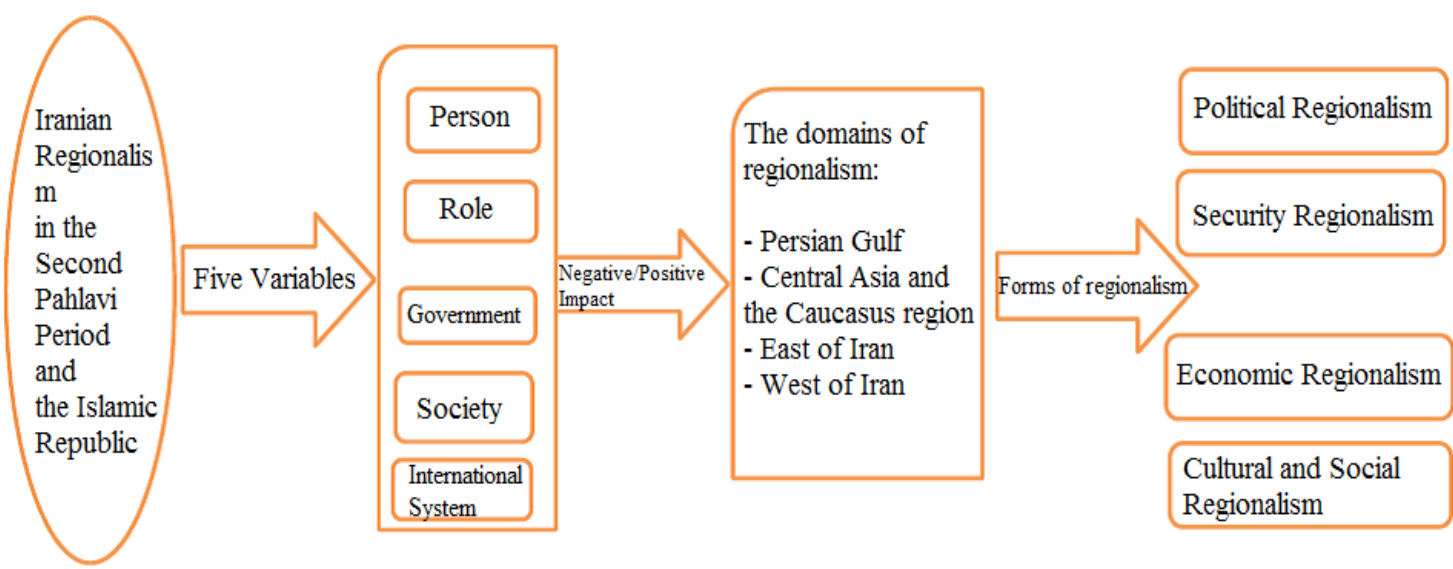

the Second Pahlavi period and the Islamic Republic.

\section{Chart 1}

\section{Conceptual model of research based on James Rosenau's five variables}

\section{Comparison of Individual Variables in the Second Pahlavi Period and the Islamic Republic}

If we want to compare the foreign policy and regionalism of these two periods according to Rosenau's first variable, we need to look at the main decision-makers of these two systems. In the second Pahlavi era of Mohammad Reza Shah and in the Islamic Republic of Iran, first Imam Khomeini and then Ayatollah Khamenei play a key role in foreign policy decision-making. The overwhelming spirit of fear and support for the presence of Mohammad Reza Shah made him increasingly interested in securing support for his policies in the region. The foundation of Mohammad Reza's regional policy was on the extreme fear of Communist overthrow, the pretense of regional cooperation and the establishment of an organization for collective security (Vaez, 2009: 21). Also, narcissism and ambition had its effects on Iran's regionalization policy. The great desire of Mohammad Reza Shah Pahlavi to achieve the role of the gendarmerie of the region at any cost reflects this fact. He was willing to give up Bahrain easily for this role. The point to be made about Mohammad Reza Shah is that his inherent fear 
and autocratic nature have led him to personally make important foreign policy decisions without trusting others and, as a result, it gives color to the role of the decisive personality in this very period.

In the Islamic Republic, this is a very deliberate issue. Both Imam Khomeini and Ayatollah Khamenei were born and raised in spiritual and religious families. Therefore, the most important issue for them is religion and attention to religious matters. The fearless spirit of uncompromising courage and pragmatism are other characteristics of these leaders of the Islamic Republic. These issues have led to dramatic changes in the direction and manner of Iran's foreign policy immediately following the victory of the Islamic Revolution.

The most important decision-makers during Imam Khomeini's leadership were Imam Khomeini as the main decision-maker, the executive elite, the Islamic Consultative Assembly, the Cabinet and the Ministry of Foreign Affairs but in this period Imam Khomeini had the main and final role in decision making in foreign policy (Rasooli Sani Abadi, 2016: 80). We see this as a sign of a relationship with the Soviet Union. Due to the personality traits of Imam Khomeini, who came from religion, and with his irreconcilable spirit, the Soviet attempt to establish a relationship with the Islamic Republic failed, Imam Khomeini called the Soviet the "little devil" and backing the East and West superpowers. Another example was Imam Khomeini's decision to continue the war with Iraq and eventually accept UN Security Council Resolution 598 and end the war with Iraq, which the Imam referred to as drinking poison.

Imam Khomeini repeatedly stated that there was no difference between the superpowers. Both are materialistic, repressive, and dominant toward the Third World. They both want to destroy the Iranian revolution and Iran must continue its struggle with the superpowers to eliminate all dependencies. In fact for the Iranian revolutionaries, although not the "Great Devil", the Soviets were considered "the Little Devil" in the camp opposed to Islam and representing socialism. Therefore, the first objective of foreign policy was to maintain the survival of the regime against two camps opposed to the East and the West (Moshaver, 2003: 283).

These cases, for example, indicate that the final decision maker in the Islamic Republic was the Imam himself. After his death, the Supreme Leader of the Islamic Republic, Ayatollah Ali Khamenei, has been conducting foreign policy in the same way as Imam Khomeini. Ideological foreign policy based on Islamic values is at the heart of this era's policy. In one of those early days after coming to the leadership, he said: "Our politics will not be subject to any East or West policy, and this is one of our principles and foundations, and there is no doubt about it and it is unchangeable. This is not politics at all; it is the basis of the system and has nothing to do with communication. Gentlemen, move in this direction and strengthen the communication based on Islamic thinking and beliefs" (Ayatollah Khamenei, August 22th 1989, quoted by Jafarzadeh Bahabadi and Khalili, 2014: 51). This issue has repeatedly appeared in the foreign policy and regionalism of the Islamic Republic and the formation of the concept of the Shiite crescent is one of them.

The point that can be drawn from the comparison of these two periods is that in both periods the variable role of the individual and the decision-maker in Iranian foreign policy and regionalism is very important. During the reign of the Shah, this was more acute. Due to his personality traits, especially during the last decade of his reign, the Shah personally took over and guided the pillars of foreign policy. The Shah's foreign policy was based on Iran's national interests and the interests of the monarchy, economic development and prosperity. In doing so, he used religion and the role of religion to serve national interests. But in the Islamic Republic this was reversed. Imam Khomeini came to the head of the Islamic state in the thought of issuing a revolution, a central nation, confronting the superpowers and regional leadership based on Islamic thought. Thus, the thinking of the Iranian leaders in the period shaped the politics of regionalism in Iran. During the Second Pahlavi period, the attempt to defuse the neighbors was achieved in order to achieve the goal of the regional gendarmerie, but in the Islamic Republic due to the issue of revolution and the release of the energy of the revolution, the fear of Iran's regional neighbors was raised in various fields. Imposing war on Iran is an example of this fear, and the support of various regional and transnational countries to Iraq in the war was a sign of the glow of the Iranian Revolution. 
Therefore, it can be said that the foreign policy decision-making model of the Second Pahlavi era and the Islamic Republic based on different cognitive systems of the main decisionmakers have produced different behaviors and in both periods the main tendency to play the role of leadership at the regional level, there was in the main decision makers. At the same time, the leadership role in the Pahlavi era was aimed at transforming Iran into a regional supreme power, while the Islamic Republic of Iran was at the forefront of the Islamic world (Rasooli Sani Abadi, 2016: 81). In each era, due to the same environmental factors, different decision-makers have interpreted the outside world as leading decision makers and adopting completely different strategies. For example, in the first period, the Pahlavi government turned to cooperating with the major powers in order to increase security and become regional power, while in the second period the government of the Islamic Republic of Iran sought to lead the Islamic world and increase its power. It has confronted great powers. This illustrates the decisive effects of the decision-makers' cognitive system on the final foreign policy decisions. The cognitive system of the Shah and Imam Khomeini has been one of the most important factors in shaping foreign policy decisions. Factors such as personality disorders, extreme narcissism, suspicion and illusion of conspiracy and ultimately security fears in the king's cognitive system, especially communism, were the most important components of his cognitive system, which had a number of features and indicators (IBID: 80). In the person of Imam Khomeini, religious sentiment is the most important symbol of his personality that has had a direct and direct impact on Iranian foreign policy.

Another point to make in comparison is that during the Shah's era, foreign policy in Iran became more military and geopolitical, increased the Shah's sensitivity and, as a result, his influence. An example of this can be seen in the case of the Three Islands and Bahrain. In the Islamic Republic, the problem is different. In this period, the more ideological foreign policy issues become, the greater the role of Iran's leader in foreign policy. The implication of this can be found in the Syrian crisis and the Shiite crescent in general. No one other than the leader in any position, from the president to the other, can act contrary to these regional policies of Iran. Instead, the slower we get from top policy issues to lesser ones, the role of the Islamic Republic's leader is diminished and the role of other decision-makers, such as the president, is increased. For example, Iran's regional policy in the North after the collapse of the Soviet Union has been a function of the presidents' role in each era.

Therefore, in the Islamic Republic there is a significant relationship between the domains of regionalism and its forms and the role of decision-makers in regional policy making. It can be said that the more the scope of Iran's regionalism shifts to the southern and Damascus areas, the more security and military it will take. And the role of the individual variable in shaping regional politics is growing. But as we move to the northern and Caucasian and western areas, such as Turkey, the economic and cultural forms of regionalism in Iran are added, thereby reducing its ideological sensitivities and reducing the role of second-rate decision makers. Adds to the Islamic Republic. Therefore, it can be said that the number of decision-makers and individual variables has increased in the period of the Islamic Republic, but this depends on the degree of sensitivity and ideology of the Islamic Republic of Iran system.

\section{A Comparative Study of the International System in the Second Pahlavi Period and the Islamic Republic}

Regarding the variable role of the international system, this variable as well as the variable of the personality of the decision-maker played a key role in shaping foreign policy decisions of the Second Pahlavi period and the Islamic Republic of Iran. The type of power distribution plays a central role in the foreign policy of countries. During the reign of the Shah, the bipolar system prevailed, and the Cold War conditions required countries around the world to join one of the two eastern or western blocs. This was inevitable for Iran, which had a very important geopolitical position. Iran was in the neighborhood of the leader of the Eastern bloc, whether or not it was influenced by it. The Shah's bitter experience of the interventions and devastations brought about by the tsarist and Soviet Russia in Iran, as well as the fear of the Toodeh Party at home, coupled with the issue of the Shah's personality traits, such as the inherent fear of communism, caused Iran's tendency. To the West and security guarantees from 
The Study of James Rosenau's Affiliation Theory with an Emphasis on the Role of Individual and International System Variables in the Analysis of Regionalism in the Second Pahlavi and Islamic Republic of Iran

the United States. Iran's accession to Western security organizations and treaties such as the Baghdad Treaty can be assessed in this regard.

Iran's foreign and regional policy during this period also developed. Acted as a regional gendarmerie to protect the interests of the Western bloc. Countering the spread of communism was in this respect. An example of that was the battle of Zafar and Iran's success in that battle. Other policies of the Iranian region during this period include Iran's assistance to Pakistan and India. Also, Iran's confrontation with Iraq and other Arab regimes that favored communism can also be analyzed. Therefore, the Shah could not have a neutral and non-aligned policy. Because Iran's position would not allow this. Iran, unwillingly, must orient itself toward one of the western or eastern blocs. Due to the characteristics of the king and the conditions of the religious community of Iran, the tendency towards the west took place. Because religion is rejected in the ideology of communism. Therefore, the changing role of the international system in the Shah's regionalism had a direct and decisive influence. As a matter of fact, the settlement of regional disputes with the Arabs and the divestment of Bahrain was also aimed at gaining a gendarme role in the region as a result of changing environmental conditions. It referred to the regional governments for self-protection by announcing Britain's withdrawal from the east of Suez and the Persian Gulf and announcing the Nixon Doctrine. Therefore, besides the Shah's personality, the most important variable of Rosenau's five variables can be regarded as the international system variable. This variable has played a very decisive role in Iranian foreign policy during the Islamic Republic.

The distribution of power in the international system, defined in terms of the number of poles of power or polarity, is the determining factor in the foreign policy of the Islamic Republic of Iran. Therefore, in shaping the foreign policy of the Islamic Republic of Iran, the priority and causal priority of systematically independent variables, in particular the distribution of relative power within the international anarchic system, should be taken into consideration. Anarchy and the relative distribution of power at the international level provide the range and factors necessary for defining the grand strategies of Iran's foreign policy, so that the international system and its anarchic structure make the Islamic Republic of Iran social to respond appropriately to its limitations and requirements. This factor alone cannot explain the short-term political choices and options in Iranian foreign policy, since the influence of systemic factors and the relative position of Iranian power indirectly and indirectly influences its foreign policy. So that systemic requirements shape the foreign policy through intermediary variables such as the structure of the Islamic Republic's government, the nature of society and the perceptions of its decision makers (Dehghani Firouzabadi, 2011: 286).

Here is an example of an interim government led by a businessman to the clergy. The business administration opted for a policy of non-compliance based on Mossadegh's negative balance, but eventually resigned. The environmental variable then led to the imposition of the Iraq war on Iran. Regional and trans-regional countries united against Iran to harness the power of the revolution. Again, influenced by Iran's environmental variables, it had to accept war. Because the United States was directly involved in the war with Iran. Next, with the collapse of the bipolar system as well as the end of the war, the opportunity to interact more with the world by reducing the ideological dimension of foreign policy and a realistic view of the international system. Domestic needs and the need to attract foreign capital played a special role. Hashemi Rafsanjani's government assumed this important role. In this way, Iran's regionalization policy could not be offensive. That is why de-stressing is on the agenda. Special attention was also given to the northern region and the countries that had just been rescued and independent from Soviet rule. In this period, strengthening regionalism was on the agenda.

Strengthening regionalism has meant increased engagement with regional countries, especially Muslim neighbors and countries in the Arab world. Some views also consider strengthening the East, including developing relations with Central Asia and the Caucasus, China, Russia, and Asia in general in the context of strengthening regionalism in Iranian foreign policy during this period (Zarei et al., 2015: 753). In any case, it was the environmental variables that led to Iran's new regionalism approach. Because of the pressing environmental pressures, the war was over and as a result, the collapse of the bipolar system provided Iran with a new opportunity to do so. In the later phase of the Khatami period, although more than the 
previous period, efforts were made to defuse the tensions, but the change in the international system caused tensions in the region and in Iran's foreign policy as a whole. The terrorist attack on the Twin Towers in the United States and in parallel with the US attack on Iraq and Afghanistan and considering Iran in the list of Axis of Evil countries, were among the environmental variables that overshadowed Iran's foreign policy. During this critical period, the Iranian government assisted Iraq and Afghanistan in its wars with the United States, but America's reluctance to Iran and its obstruction of the Saadabad treaty offended Iranian national pride. Confronting the international system, stressing the regional environment, and passing several Security Council resolutions against Iran, and imposing widespread sanctions on Ahmadinejad's achievements. Regionally, Iran played a more proactive role in supporting Palestinian militant groups and fighting Israel. In addition to imposing international sanctions, Iran's nuclear issues during this period also provoked regional states against Iran. Until the clerical government, with the slogan of tact and hope, tried to counteract these threats.

Still impacted by the international environment, Iran's nuclear case, despite initial positive gains, did not come to fruition with the United States' withdrawal, and Iran was historically subject to the most severe international sanctions. Regionally, tensions were also high in the region as the crisis in Syria, Iraq, as well as in Yemen, Bahrain, and the Arab-Israeli war in Iran continued. Infact, proxy wars and sectarian and ideological tensions and conflicts form the basis of Iran's regionalism during this period.

It is noted that in both the Second Pahlavi period and the Islamic Republic, Iran's foreign and regional policy was influenced by the international system. In both periods there has been an attempt to play a regional role. Indeed, one of the important issues that has been raised has been Iran's continued quest for regional power. Iran has always wanted to lead the region. This issue is a common feature of the Shah and the Islamic Republic period (Bayar, 2019: 38), although its type is different. However, in both periods Iran has been trying to emerge as a regional leader and regional power. Therefore, the balance of power at the global and regional levels has greatly influenced Iran's policy in the two periods. During the reign of Shah, Iran under the influence of the bipolar system was inclined to the West, but in the period of the Islamic Republic, both in the period of the bipolar system and afterwards, the basis of Iran's foreign and regional policy was to confront the West and its supportive countries and manifestations of the West in the area. Therefore, the foreign policy of the Islamic Republic in the world and in the region has only focused on Western structures, including on US actions to bring the Islamic Republic to its knees. Examples include the formation of the Shiite crescent and Iran's support for the regime of Bashar al-Assad against the United States and Saudi Arabia, which support opposition groups. 
The Study of James Rosenau's Affiliation Theory with an Emphasis on the Role of Individual and International System Variables in the Analysis of Regionalism in the Second Pahlavi and Islamic Republic of Iran

Table 1

The Application of Rosenau's Theory (Individual Variables and the International System) Compared to Iran's Regionalism in the Second Pahlavi Period and the Islamic Republic

\begin{tabular}{|c|c|c|}
\hline $\begin{array}{l}\text { Rosinau's } \\
\text { five variables }\end{array}$ & $\begin{array}{l}\text { anian Regionalism in the Second } \\
\text { ahlavi Period }\end{array}$ & Iranian Regionalism in the Islamic Republic \\
\hline Person & $\begin{array}{l}\text { Properties and Attitudes of } \\
\text { Mohammad Reza Shah including; } \\
\text { Westernization: Membership in the } \\
\text { Baghdad and Sento Pacts; continued } \\
\text { oil sales to Israel, agreeing to } \\
\text { Bahrain's independence; financial } \\
\text { assistance to Afghanistan and } \\
\text { Pakistan. } \\
\text { Supremacy: Acceptance and Role of } \\
\text { the Gendarmerie; Suppression of } \\
\text { Zafar Insurgents; Restoration of } \\
\text { Iran's Sovereignty over the Three } \\
\text { Gulf Islands } \\
\text { Nationalism: Help Pakistan by } \\
\text { sending troops from the military } \\
\text { along with military equipment to } \\
\text { clear and destroy Baloch separatist } \\
\text { guerrillas (with the aim of } \\
\text { preventing the Baluchis from joining } \\
\text { them). }\end{array}$ & $\begin{array}{l}\text { Characteristics and Attitudes of Imam Khomeini } \\
\text { and Supreme Leader and Presidents: } \\
\text { Western spirit of anti-Semitism / arrogance: } \\
\text { Including hostility and outright hostility to Israel; } \\
\text { Islamism: Support for Islamic Resistance Groups } \\
\text { in Palestine,... } \\
\text { Shi'ism: Support for Shiite resistance groups in the } \\
\text { region, including Hezbollah in Lebanon; } \\
\text { Ansarullah Yemen; Shiite Al-Iraq and Shiite } \\
\text { crescent } \\
\text { Supremacy: Leadership of the Islamic World } \\
\text { (Umm al-Qari); Iran's Membership in Non- } \\
\text { Aligned Movement } \\
\text { An optimistic view of the international system and } \\
\text { a belief in the politics of de-escalation and } \\
\text { constructive engagement in foreign policy: } \\
\text { especially during the presidency of Mr. Hashemi } \\
\text { Rafsanjani, Khatami, and Rouhani; } \\
\text { Improvement of relations with the Gulf States } \\
\text { Oriental Policy: Expanding and Strengthening } \\
\text { Iran's Cooperation with ECO (From Hashemi } \\
\text { Rafsanjani's Period); Developing and Expanding } \\
\text { Relations with Russia and China (Ahmadinejad's } \\
\text { Period) }\end{array}$ \\
\hline $\begin{array}{l}\text { Internat } \\
\text { System }\end{array}$ & $\begin{array}{l}\begin{array}{l}\text { Bipolar system; Cold War era; } \\
\text { Truman doctrine; }\end{array} \text { British } \\
\text { withdrawal; Nixon doctrine } \\
\text { Indicative Trends: Iran's } \\
\text { Membership in Baghdad and Sento } \\
\text { Pact; Role of Gendarmerie in the } \\
\text { Region; Iran's Abandonment of the } \\
\text { Hirmand River to Draw US-led } \\
\text { Western Bloc of Afghanistan; In the } \\
\text { dispute with India over Kashmir and } \\
\text {... }\end{array}$ & $\begin{array}{l}\text { Neither Eastern nor Western politics, the } \\
\text { continuation of the bipolar system; the collapse of } \\
\text { the Soviet Union in the early 1990s; the events of } \\
\text { September 11, 2001. } \\
\text { Significant trends: Iran's support for the } \\
\text { Mujahideen of Afghanistan against the Soviet } \\
\text { invasion; Adoption of a policy of deterioration } \\
\text { following the collapse of the Soviet Union; } \\
\text { Improvement of Iran's relations with Saudi Arabia } \\
\text { in the final years of Hashemi's presidency, } \\
\text { especially cooperation between the two countries } \\
\text { in OPEC; Iran's relations with Russia and the } \\
\text { newly established Central Asian and Caucasian } \\
\text { countries; flexibility on the Hirmand right with } \\
\text { respect to a number of regional and international } \\
\text { expediencies, greater regional cooperation, and } \\
\text { more. }\end{array}$ \\
\hline
\end{tabular}

\section{Conclusion}

Based on the variables mentioned in Rosenau, we can say that in the second Pahlavi period, the most important variable affecting Iran's foreign and regional policy was the international system variable. Iran had to adopt a particular approach under a bipolar system and dependence on the Western bloc. The next variable is the personality of the decision maker and the characteristics and moods of Mohammad Reza Shah, who is in the next phase of the 
international system variable. Features such as a sense of inferiority, fear, narcissism, etc., made him, at first, a fundamental fear of the Soviet Union and the Tudeh Party, and subsequently joined the Western bloc and sought security guarantees from the West. He also seeks leadership and empowerment in the region to satisfy his sense of narcissism and ambition, along with other variables. This sentiment was embedded in the spirit of antiquity and imperialism of ancient Iran. It was pointed out that with the personalization of power in the first person of the country, the king, one could not conceive of a role for government and society. Because formal governmental and non-governmental institutions and public opinion and parties in society and other issues related to government and community variables were under the opinion and extreme will of the first person. Therefore, the role of the decision maker and the extent of decision-making authority is the third most influential variable in this period. And then there is the variable of government and then society.

In the case of the Islamic Republic, there are not many changes in the order of these variables. Because, according to Rosenau's theory, this is a general rule that in less developed systems in terms of democratic structures, the role of society and government is less than that of the decision-maker and the international system. But in any case, a pillar of the Islamic Republic's system is based on the republican system and referendum. So this variable must also be included in the calculations. In general, the role of the decision-making personality in the Islamic Republic seems to be prioritized over other variables. In the Islamic Republic, Imam Khomeini, and then Ayatollah Ali Khamenei, as the leaders of the Islamic Republic's system of conducting foreign policy based on the ideology, religion and ideals of Islam, was observed. This is due to the religious personality and the religious spirit of these people. Also, their uncompromising spirit, patience, and courage led them to pursue a policy of non-commitment at the critical stages of the revolution and at the stage of the bipolar system and to oppose the international system with the slogan of neither eastern nor western. It was seen how the then Prime Minister, Mehdi Bazargan, was fired because of his policy incompatibility with the Imam. The result is that the decision-making personality of the leaders in the Islamic Republic plays a major role in foreign and regional policy making.

The next variable is the international system. This variable has had a significant impact on the foreign policy of the Islamic Republic. Whether in the bipolar period or in the collapse of the Eastern Bloc system. It was seen how the collapse of the Soviet Union and the end of the Cold War activated Iran's regional policy and regional deterioration. In the ensuing period, the United States has practically surrounded Iran in the region under the pretext of fighting extremism as a result of the Iraq-Afghanistan war. Therefore, Iran's regional policies are clearly seeking to thwart US actions and are clearly in opposition to US-backed governments and their policies.

\section{References}

Azghandi, Alireza. (2007). Foreign policy of the Islamic Republic of Iran. Tehran: Ghoomes Publications.

Barzegar, Kayhan. (2009). Regionalism in Iranian Foreign Policy. Central Eurasian Studies, 2(5), 40-23.

Bayar, Tugba. (2019). "Multiple Dualities: Seeking the Patterns in Iran's Foreign Policy". All Azimuth, 8, 36-54.

Dehghani Firouzabadi, Seyed Jalal. (2011). Neoclassical Realism and Foreign Policy of the Islamic Republic of Iran. Foreign Policy Quarterly, 25(2), 297-276.

Fath Tabar Firouzjai, Mohsen. (2015). Analysis of the Second Pahlavi Foreign Policy in Bahrain's Separation from Iran Based on the Theory of James Rosenau. Persian Gulf Cultural and Political Studies Quarterly, 2(6), 59-73.

Houshang Mahdavi, Abdolreza. (2010). Iranian Foreign Policy in the Pahlavi Period, Peykan Publishing. 
The Study of James Rosenau's Affiliation Theory with an Emphasis on the Role of Individual and International System Variables in the Analysis of Regionalism in the Second Pahlavi and Islamic Republic of Iran

Jafarzadeh Bahabadi, Hossein, Khalili, Mohsen. (2014). Reflection of Foreign Policy Orientation in Ayatollah Khamenei's Speeches and Writings 1989-2009. Foreign Policy Quarterly, 28(1), 41-69.

Mansouri Moghaddam, Jahanshir, Esmaili, Ali. (2011). An Analysis of the Foreign Policy of the Islamic Republic of Iran During President Mahmoud Ahmadinejad's View of James Rosenau's Connection Model. Journal of Politics, Journal of the Faculty of Law and Political Science, 41(1), 300-283.

Mohammadian, Ali, Rezaei, Alireza. (2015). Explaining the Foreign Policy of the Islamic Republic of Iran in the Hassan Rouhani Period from the Perspective of James Rosenau's Connection Theory. Conference on New Horizons in the Humanities of Future Studies and Empowerment, January 28, Shiraz.

Moshaver, Ziba. (2003). "Revolutions, Theocratic Leadership and Iran's Foreign Policy: Implications for Iran - Europe Relations". The Review of International Affairs, 3(2), 283-305.

Naqibzadeh, Ahmad. (2009). Iran's foreign policy decision-making process (challenges, harms, and solutions). Tehran: Vice chancellor for research, Islamic Azad University.

Rasooli Sani Abadi, Elham. (2016). A Comparative Study of the Second Pahlavi Period (19631978) and the Islamic Republic (1979-1989), A Critique of Foreign Policy DecisionMaking. Journal of Texts and Programs in Humanities, 16(3), 77-96.

Rosenau, James. (1971). The Scientific Study of Foreign Policy. New York: The Free Press.

Sadeghi, Sayed Shamsuddin. (2017). Coalition building in the international system; the dilemma of foreign policy of the Islamic Republic of Iran. Tehran: Farzan.

Seifzadeh, Hossein. (2003). Principles of International Relations. Tehran: The rate.

Vaez, Nafiseh. (2009). The Impact of Decision Making on the Decision-Making Process in Iranian Foreign Policy in the Last Decade of Pahlavi Government. Journal of the Iranian Society of History, 1(2), 2-33.

Zarei, Bahador and others. (2015). "Regionalism and its Challenges in the Foreign Relations of the Islamic Republic of Iran. Human Geography Research, 47(4), 758-743.

Zarei, Bahador. (2015). Regionalism and its Challenges on Foreign Relations of the Islamic Republic of Iran. Human Geography Research, 47(4), 732-755. 